\title{
Partial Replacement of Dietary Methionine with Betaine and Choline in Heat-Stressed Broiler Chickens
}

\author{
Mohammad Mahmoudi, Arash Azarfar and Heshmatollah Khosravinia \\ Department of Animal Science, Faculty of Agriculture, Lorestan University, Khorramabad, Iran
}

\begin{abstract}
We conducted two trials to evaluate the methionine-sparing effects of choline (Chol) and betaine (Bet), and their effects on growth performance and blood antioxidative potential in heat-stressed broiler chickens fed methionine (Met)-deficient diets. We used 360 1-day-old broiler chicks (Ross 308) in a completely randomized study with 5 replicate pens of 12 birds each. After Day 21 , we raised the temperature to $35 \pm 3^{\circ} \mathrm{C}$ using an automated air-forced heater for 12 hours/day from 8 am to 8 pm to expose the birds to heat stress. In Trial 1, the treatments comprised a negative control (control-; $1200 \mathrm{mg} / \mathrm{kg}$ Met-deficient), a positive control (control+; recommended level of Met), 280Chol (control- plus $280 \mathrm{mg} / \mathrm{kg} \mathrm{Chol),} \mathrm{560Chol} \mathrm{(control-} \mathrm{plus} 560 \mathrm{mg} / \mathrm{kg} \mathrm{Chol}$ ), 320Bet (control- plus $320 \mathrm{mg} / \mathrm{kg}$ Bet), and 640Bet (control- plus $640 \mathrm{mg} / \mathrm{kg}$ Bet); and in Trial 2, the treatments comprised a negative control (control-), a positive control (control+), 140Chol+160Bet (control- plus $140 \mathrm{mg} / \mathrm{kg}$ Chol and $160 \mathrm{mg} / \mathrm{kg} \mathrm{Bet}$ ), 280Chol+160Bet (controlplus $280 \mathrm{mg} / \mathrm{kg}$ Chol and $160 \mathrm{mg} / \mathrm{kg} \mathrm{Bet),} \mathrm{140Chol+320Bet} \mathrm{(control-} \mathrm{plus} 140 \mathrm{mg} / \mathrm{kg}$ Chol and $320 \mathrm{mg} / \mathrm{kg} \mathrm{Bet}$ ), and $280 \mathrm{Chol}+320$ Bet (control- plus $280 \mathrm{mg} / \mathrm{kg}$ Chol and $320 \mathrm{mg} / \mathrm{kg} \mathrm{Bet}$ ). Compared with the other treatments, the feed conversion ratio (FCR) was improved in the $280 \mathrm{Chol}$ and control+ groups in Trials 1 and $2(P<0.05)$. In Trial 2, the cost of meat production for the entire experimental period (1-42 days) was higher in the 140Cho+320Bet-fed birds than in the other birds $(P<0.05)$, except the control- birds. Supplementing diets with $280 \mathrm{mg} / \mathrm{kg}$ of Chol significantly reduced the serum concentration of uric acid compared with the control+ group $(P<0.05)$. Our results indicate that the Met requirements of heat-stressed broiler chickens can be reduced by $20 \%(1200 \mathrm{mg} / \mathrm{kg})$ if the diet is supplemented with $280 \mathrm{mg} / \mathrm{kg}$ of Chol.
\end{abstract}

Key words: acute phase protein, anti-oxidant status, broiler, organs, performance

J. Poult. Sci., 55: 28-37, 2018

\section{Introduction}

Heat stress (HS) is defined as a negative balance between the net amount of energy flowing from an animal's body to its surrounding environment and the amount of heat energy produced by the animal (Lara and Rostagno, 2013). The effects of HS on performance in domestic fowl are frequently investigated, and the results have been carefully reviewed by many researchers (Charles, 1986; Mitchell and Carlisle, 1992; Mahmoud and Yaseen, 2005). Broiler chickens are very susceptible to high environmental temperatures because they lack sweat glands and have a high metabolic rate (Geraert et al., 1993). The problems associated with HS in broilers include respiratory alkalosis (Teeter et al., 1985), decreased performance (Howlider and Rose, 1989; Cooper and Washburn, 1998; Akşit et al., 2006), decreased breast

Received: June 8, 2017, Accepted: June 23, 2017

Released Online Advance Publication: August 25, 2017

Correspondence: Dr. Arash Azarfar, Department of Animal Science, Faculty

of Agriculture, Lorestan University, Khorramabad, Iran.

(E-mail: arash.azarfar@gmail.com) yield (Akşit et al., 2006), and oxidative stress (Mujahid et al., 2005; Lin et al., 2006a). Under HS conditions, chickens eliminate excess heat by increasing their respiratory rate, which may result in an acid/base imbalance known as respiratory alkalosis (Borges et al., 2004; Toyomizu et al., 2005). Moreover, HS leads to increased levels of reactive oxygen species (ROS), possibly due to disruption of the electron transport assemblies of the cell membrane (Ando et al., 1997). ROS play an important role in many biological systems, including the body's response to infection, heavy metals, and ethanol toxicity, as well as other conditions (Donati et al., 1990).

For many decades, researchers have sought nutritional ways to moderate the negative impact of HS on broilers. Choline (Chol) is a water-soluble, essential quaternary amine that plays an important role as a methyl donor in the conversion of homocysteine to methionine (Met) (Zhang et al., 2013). Studies on Chol have mainly focused on its methionine-sparing role (Keshavarz and Austic, 1985; Waldroup et al., 2006). However, although Chol is essential, it may also be beneficial for improving the efficiency of 
energy and protein utilization (Rao et al., 2001). Chol is readily oxidized to betaine (Bet), which also functions as a methyl donor and an osmolyte (Criag, 2004). Chol also plays an important role in lipid metabolism in the liver, thereby preventing the abnormal accumulation of fat in that organ (Rao et al., 2001). Furthermore, Chol acts as an osmolyte; it plays an important role in maintaining normal cell volume and can produce Bet and glycerol-phosphocholine. The latter is a dominant osmolyte in kidney cells, and protects renal medullary cells from hypertonicity of the interstitial fluid (Nakanishi and Burg, 1989).

Betaine (Bet), also known as trimethylglycine, is a zwitterionic quaternary ammonium compound and a neutrally charged osmolyte (Yancey et al., 1982) that may be beneficial to the performance of broilers under extreme ambient temperatures. Bet has been widely evaluated for its methionine-sparing, choline-sparing (Patil et al., 2007), performance-enhancing, acid/base-balancing, and osmolytic (Criag, 2004) effects in broilers (Waldroup and Fritts, 2005). Methionine re-methylation catalyzed by betaine-homocysteine methyl transferase (BHMT) is involved in the regulation of osmosis (Schafer et al., 2007). Bet can act as an antioxidant agent in low-methionine diet-induced oxidative stress in broilers (Alirezaei et al., 2012). However, methionine has a potentially protective role in the scavenging of free radicals generated indirectly by lead, including those formed during xenobiotic-induced lipid peroxidation and those caused by reduced antioxidant enzyme activities and vitamin levels (Caylak et al., 2008). Moreover, Bet can replace up to $25 \%$ of Met without adversely affecting the production performance of the broilers, indicating that up to $25 \%$ of dietary Met is involved in methylation reactions in broilers (Sun et al., 2008). Therefore, the objectives of the present study were to evaluate the effects on production performance, anti-oxidative indices, and certain blood metabolites of supplementing a Met-deficient diet with Chol and Bet in broiler chickens reared in HS conditions.

\section{Materials and Methods}

\section{Animals and Diets}

This experiment consisted of two trials. In Trial 1, 360 1day-old male and female broiler chicks (Ross 308) were randomly assigned to 1 of 6 experimental treatment groups: a negative control group (control-; $1200 \mathrm{mg} / \mathrm{kg}$ Met-deficient), a positive control group (control+; recommended level of Met, without Met deficiency), a 280Chol group (negative control diet plus $280 \mathrm{mg} / \mathrm{kg} \mathrm{Chol}$ ), a 560Chol group (negative control diet plus $560 \mathrm{mg} / \mathrm{kg} \mathrm{Chol}$ ), a 320Bet group (negative control diet plus $320 \mathrm{mg} / \mathrm{kg} \mathrm{Bet}$ ), and a 640Bet group (negative control diet plus $640 \mathrm{mg} / \mathrm{kg}$ Bet) in 5 replicate pens of 12 birds each. In Trial 1, the replacement of Met with Bet or Chol provided a similar number of methyl groups (an equivalence) to that provided by $1200 \mathrm{mg}$ (280Chol and $320 \mathrm{Bet}$ ) and $2400 \mathrm{mg}$ (560Chol and 640Bet) of methionine as a methyl donor.

In the second trial, we assessed the effects of supplementing a Met-deficient diet (similar to Trial 1) with a combi- nation of Chol and Bet on production performance, certain blood metabolites, liver enzymes, and the blood antioxidative status of heat-stressed broiler chickens. We assigned 360 (Ross 308) 1-day-old chicks to each of the 6 experimental treatments in 5 replicate pens of 12 birds each. The treatments comprised control-, control+, 140Chol+ 160Bet (negative control diet plus $140 \mathrm{mg} / \mathrm{kg}$ Chol and 160 $\mathrm{mg} / \mathrm{kg} \mathrm{Bet}$ ), 280Chol+160Bet (negative control diet plus 280 $\mathrm{mg} / \mathrm{kg} \mathrm{Chol} \mathrm{and} 160 \mathrm{mg} / \mathrm{kg} \mathrm{Bet}$ ), 140Chol+320Bet (negative control diet plus $140 \mathrm{mg} / \mathrm{kg}$ Chol and $320 \mathrm{mg} / \mathrm{kg} \mathrm{Bet}$ ), and $280 \mathrm{Chol}+320$ Bet (control diet plus $280 \mathrm{mg} / \mathrm{kg}$ Chol and 320 $\mathrm{mg} / \mathrm{kg}$ Bet). In Trial 2, the replacement of Met with Bet or Chol provided a similar number of methyl groups (an equivalence) to that provided by $1200 \mathrm{mg}(140 \mathrm{Chol}+160 \mathrm{Bet}), 1800$ $\mathrm{mg}$ (280Chol+160Bet and 140Chol+320Bet), and $2400 \mathrm{mg}$ (280Chol+320Bet) of methionine as a methyl donor.

Each pen $(1 \times 1.2 \mathrm{~m})$ was provided with a feeder $(1 \mathrm{~m}$ long) and a bell-type drinker. In order to expose birds to HS in both trials, after Day 21 the house temperature was raised to $35 \pm 3^{\circ} \mathrm{C}$ by an automated air-forced heater 12 hours/day from 8 am to $8 \mathrm{pm}$. All birds were maintained under the same temperature condition (under $60 \%$ relative humidity) in tunnel ventilated house and lighting control system $(23 \mathrm{~h}$ light/d- 30 lux) during the entire period of study. The basal diet (control diet) was formulated based on a corn-soybean meal for the starter (0-21 days) and growing (22-42 days) periods. Diets were formulated to meet or slightly exceed all nutrient recommendations (except for Met) for broilers. (Table 1; Aviagen, 2014). Supplemental Bet (Betafin, Biochem, Lohne, Germany, 96\% betaine) and choline (Choline chloride, Hylen, Qingdao, China; 60\% choline chloride) was substituted for equivalent amounts of corn in the basal diet. Birds had free access to feed and water throughout the experimentation period. Light was continuous during the first day and a $23 \mathrm{~h}$ : $1 \mathrm{~h}$ lightening: darkness regimen was employed afterwards.

\section{Sample Collection and Analytical Determination}

Live body weight (BW) and feed intake (FI) were recorded on a weekly basis, and the data were used to calculate the average daily weight gain (ADWG), the average daily feed intake (ADFI), and the feed conversion ratio (FCR) for each phase. Viability, economic factors including the European efficiency factor (EEF), and the cost of producing $1 \mathrm{~kg}$ of live weight $(\mathrm{Cm})$ were calculated using the following formulae (Bera et al., 2010; Lup et al., 2012):

Viability $=\{1-(\mathrm{n}$ of dead birds/total birds $)\} \times 100$

$\mathrm{EEF}=\{\mathrm{BW} \times$ viability $\times 100 /(\mathrm{FCR} \times$ age $)\}$

where EEF is the European efficiency factor and BW is the average body weight $(\mathrm{kg})$. Age was measured in days. The cost of producing $1 \mathrm{~kg}$ of live weight was calculated as:

$$
\mathrm{Cm}=\mathrm{FCR} \times \mathrm{Cf}
$$

where $\mathrm{Cm}$ is the cost of producing $1 \mathrm{~kg}$ of live weight, FCR is the feed conversion ratio, and $\mathrm{Cf}$ is the cost of feed per $\mathrm{kg}$.

At 28 ( 7 days after heat treatment) and 42 days of age, two birds from each pen were randomly selected for blood sampling via a wing vein. The serum was harvested by centrifuging the blood samples at $3000 \times g$ for $20 \mathrm{~min}$ at $4{ }^{\circ} \mathrm{C}$ 
Table 1. Feed ingredients and nutrient composition of basal diet (control) during different growth periods

\begin{tabular}{|c|c|c|}
\hline Feed ingredients $(\mathrm{g} / \mathrm{kg})$ & Starter ( $0-21$ days $)$ & Grower (22-42 days) \\
\hline Corn grain ${ }^{1}$ & 499.7 & 585.8 \\
\hline Soybean meal & 436.4 & 341.2 \\
\hline Soybean oil & 23.1 & 40.5 \\
\hline Ca-carbonate & 13.1 & 11.0 \\
\hline Di-calcium phosphate & 12.8 & 7.7 \\
\hline DL-methionine & 1.8 & 0.9 \\
\hline L-lysine $\mathrm{HCl}$ & 2.0 & 1.2 \\
\hline L-threonine & 1.1 & 0.5 \\
\hline Na-bicarbonate & 1.7 & 1.8 \\
\hline Salt & 2.7 & 2.7 \\
\hline Vitamins and minerals Premix ${ }^{2}$ & 5.0 & 5.0 \\
\hline Multi-enzyme $^{3}$ & 0.5 & 0.5 \\
\hline Phytase $^{4}$ & 0.1 & 0.1 \\
\hline \multicolumn{3}{|l|}{ Analyses (calculated g/kg) } \\
\hline $\operatorname{ME}(\mathrm{MJ} / \mathrm{kg})$ & 12.55 & 13.39 \\
\hline Crude protein & 232.3 & 200.0 \\
\hline Methionine & 4.88 & 3.67 \\
\hline Methionine + cysteine & 8.30 & 7.10 \\
\hline Lysine & 12.80 & 10.30 \\
\hline Threonine & 8.60 & 6.90 \\
\hline Calcium & 10 & 7.9 \\
\hline Available phosphorus & 5.0 & 3.95 \\
\hline Sodium & 1.6 & 1.6 \\
\hline \multicolumn{3}{|c|}{ 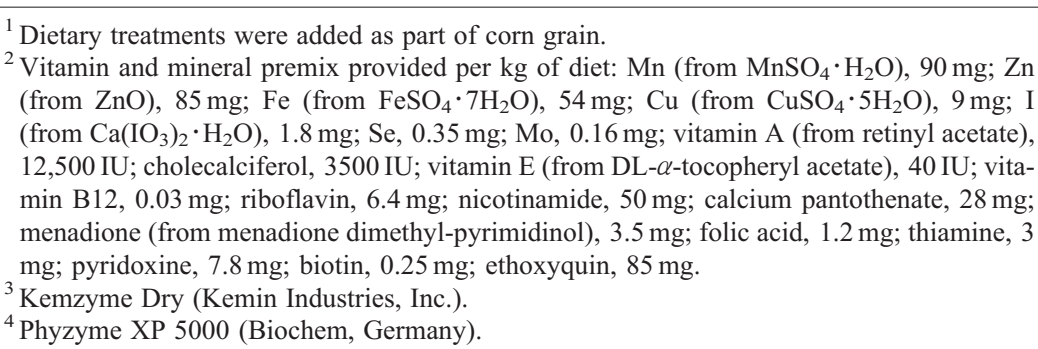 } \\
\hline
\end{tabular}

using a benchtop centrifuge (Pars Azma, Tehran, Iran), and stored at $-20^{\circ} \mathrm{C}$ until required. We determined serum levels of total protein (TP), albumin (ALB), glucose (GLU), total cholesterol (CHL), high-density lipoprotein (HDL), lowdensity lipoprotein (LDL), very low-density lipoprotein (VLDL), triglycerides (TG), calcium (Ca), phosphorus (P), uric acid, alkaline phosphatase (ALP), aspartate amino transferase (AST), and alanine amino transferase (ALT) using commercial kits (Pars Azmoon, Tehran, Iran). Non-esterified fatty acids (NEFAs; FA115, Randox, Crumlin, UK), total antioxidant status (TAS; NX2332, Randox), glutathione peroxidase (GPx; RS 506-supplementary pack MS 181, Randox), and superoxide dismutase (SOD; SD 125, Randox) were assayed colorimetrically using the reagent kits indicated and an Alcyon 300 automated biochemical analyzer (Abbott Laboratories, Illinois, US) following the manufacturers' instructions. The serum amyloid A (SAA) concentration was measured with a CSB- EQ027630CH kit (Cusabio, China) equipped with an enzyme-linked immunosorbent assay (ELISA) reader machine (Stat Fax 4200, Awareness Tech- nology Inc. Palm City, FL, US). The serum concentration of ceruloplasmin (CEP) was measured using the method described by Sunderman and Nomoto (1970). All analyses were performed twice.

When they were 42 days old, two birds from each pen were randomly selected to provide blood samples. They were slaughtered, processed, and the proportional weight of the internal organs (as a percentage of the carcass weight) including the proventriculus, gizzard, liver, spleen, heart, and bursa of Fabricius were recorded. The total lipid content of the liver was assayed according to the method described by Folch et al. (1957).

\section{Statistical Analysis}

The data were analyzed using the GLM procedure of SAS 9.1 (SAS, 2003) according to the following model:

$$
\mathrm{Yij}=\mu+\mathrm{Ti}+\mathrm{eij}
$$

where $\mu$ is the overall mean, $T_{i}$ is the fixed effect of treatments, and $\mathrm{e}_{\mathrm{ij}}$ is the random residual error. Means were partitioned using Duncan's Multiple Range Test (Duncan, 1955). For all statistical analyses, significance was declared 
at $P \leq 0.05$, unless otherwise stated.

\section{Results and Discussion}

\section{Production Performance}

In Trials 1 and 2, the overall ADFI and ADWG were not affected by dietary treatments $(P>0.05$; Tables 2 and 3$)$.

In Trial 1, supplementing Met-deficient (control-) diets with $280 \mathrm{mg} / \mathrm{kg}$ Chol, $560 \mathrm{mg} / \mathrm{kg}$ Chol, and $320 \mathrm{mg} / \mathrm{kg}$ Bet resulted in similar overall FCRs (Days 1-42) compared with the control+ group (Table 2), which agreed with the findings reported by Sun et al. (2008). However, the control- diet with $640 \mathrm{mg} / \mathrm{kg}$ of Bet significantly increased the overall FCR of the birds compared with the control+ group (Table 2; $P<0.05)$. Furthermore, only the FCR $640 \mathrm{mg} / \mathrm{kg}$ Bet-fed and control+-fed birds exhibited significant differences $(P$ $<0.05)$. In Trial 2 , significant differences were observed in the FCR for the starting period as well as for the overall FCR (1-42 days) among the dietary groups (Table $3, P<0.05$ ). Feeding birds with 140Chol+160Bet, 280Chol+160Bet, and $280 \mathrm{Cho}+320 \mathrm{Bet}$ diets resulted in similar overall FCRs compared with the control+ birds (Table $3 . P>0.05$ ). The results showed that $20 \%$ of dietary Met, which is probably needed for methylation processes in broiler chickens, can be replaced by $280 \mathrm{mg} / \mathrm{kg}$ Chol or $320 \mathrm{mg} / \mathrm{kg}$ Bet (as a methyl group donor; Trial 1), or by a combination of $140 \mathrm{Chol}+160 \mathrm{Bet}$ (Trial 2), with no adverse effects on ADFI, ADWG, or FCR in growing birds. In agreement with the findings reported by Sun et al. (2008) and Esteve-Garcia and Mack (2000), the methyl donor compounds used in the present study successfully replaced Met, and increased the weight of the broiler chicks. Azadmanesh and Jahanian (2014) found that dietary supplementation with Chol reduced FCR and ADFI in broiler chicks reared under normal conditions. Moreover, Rao et al. (2011) reported that supplementing Met-deficient diets with Bet increased feed efficiency and weight gain.

In Trial $1, \mathrm{EEF}, \mathrm{Cm}$ in the starter and grower periods, and viability were not affected by the treatments (Table 2). However, overall Cm (1-42 days) was lower in the $280 \mathrm{Chol}$ group compared with the other treatments, with the single exception of 320 Bet-fed birds $(P<0.05)$. In Trial 2 , viability and $\mathrm{Cm}$ in the grower period were not affected by dietary treatments (Table 3), but control+ and 280Chol+320Bet-fed chicks had a higher EEF and a lower Cm (1-21 days) than the control- chicks $(P<0.05)$. In Trial 2, the overall EEFs (1-42 days) were similar in the control+ birds and those fed Met-deficient diets supplemented with combinations of Chol and Bet (Table 3 ). The cost of producing $1 \mathrm{~kg}$ of live weight was similar in chicks fed control+ diets and those fed Metdeficient diets supplemented with combinations of Chol and Bet (Table 3). According to the results given in Tables 2 and $3,20 \%$ of the dietary Met requirements could be replaced with each level of $280 \mathrm{mg} / \mathrm{kg}$ of Chol and/or Bet (with the exception of $640 \mathrm{Bet}$ and $140 \mathrm{Chol}+320 \mathrm{Bet}$ ) tested in this experiment, with no negative effects on production performance. Interestingly, the $280 \mathrm{Chol}$-fed birds had a significantly lower $\mathrm{Cm}$, even compared with the control+ birds. This reduction in $\mathrm{Cm}(0.26 \$)$ was owing to lower feed costs and improved FCRs, which are economically beneficial for the producer.

\section{Organ Weights}

In Trial 1, the relative weight of a thigh plus drumstick was lower in the 280Chol-fed birds than in the control chicks $(P$ $<0.05$ ), but was similar among the birds receiving other dietary treatments (Table 4). The relative weight of the proventriculus increased in birds fed with the diet containing 640Bet compared with the control-, control+, and 560Cholfed birds $(P<0.05)$, but was similar to the other birds (Table 4). In Trial 2 , the relative weight of the gizzard was greater in birds fed diets fortified with 280 Chol+320Bet compared with the other birds with the exception of birds fed on a 280 Cho+160Bet diet (Table 5). The relative weight of the gastrointestinal tract is a well-known indicator of its development (Nir et al., 1994; Hetland et al., 2003). An increase in the relative weight of the proventriculus in chickens fed a 640Bet (Trial 1) should be considered an indicator of greater anatomical development and increased acid and enzyme secretion in the same segment. An increase in the relative weight of the gizzard in the chicks fed 280 Chol+320Bet (Trial 2) should have resulted in increased gizzard movement, and consequently increased feed digestibility and improved production performance, but such an effect was not observed in the present study. In Trial 2 , the relative weight of the bursa of Fabricius increased in the chicks fed with $140 \mathrm{Chol}+320 \mathrm{Bet}$ (equivalent to $1800 \mathrm{mg}$ of Met) and 280 Chol+320Bet (equivalent to $2400 \mathrm{mg}$ of Met) compared with those fed Met-deficient diets supplemented with either 140 $\mathrm{mg} / \mathrm{kg}$ Bet plus $160 \mathrm{mg} / \mathrm{kg}$ Bet or with $280 \mathrm{mg} / \mathrm{kg}$ Chol plus $160 \mathrm{mg} / \mathrm{kg}$ Bet $(P<0.05)$. Moreover, the relative weight of the bursa of Fabricius was numerically higher in chicks fed $140 \mathrm{Chol}+320 \mathrm{Bet}$ and $280 \mathrm{Chol}+320 \mathrm{Bet}$ than in the control+ birds $(22.2 \%$ higher; Table 5$)$. This indicates that in heatstressed chicks, supplementing a Met-deficient diet with at least $320 \mathrm{mg} / \mathrm{kg}$ Bet in combination with Chol may improve the immune response. Swain and Johri (2000) reported that Bet and Chol improve the immune response by acting as coccidiostat enhancers in broilers. Interestingly, the relative liver weight was greater in the $280 \mathrm{Chol}$-fed chicks than in the Bet-fed chicks $(P<0.05)$. This was unexpected because we anticipated a lower total lipid content of the liver in the Cholfed chicks than in the other birds. Rao et al. (2001) observed that liver fat content decreased in broiler breeders fed a Metdeficient diet supplemented with Chol. Neto et al. (2000) reported that the level of liver lipids was not affected by dietary Bet supplementation. However, we observed a reduction in liver lipid content in birds fed with 280Chol+ 160Bet (Trial 2).

\section{Blood Parameters}

The blood biochemical factors assessed in Trials 1 and 2 were similar among the dietary treatments, with the single exception of LDL (Tables 6 and 7, respectively). Feeding chickens a Met-deficient diet supplemented with $320 \mathrm{mg} / \mathrm{kg}$ of Bet elevated the serum LDL concentration by approximately 66 and 55\% compared with those grown on a control+ diet or a diet supplemented with $560 \mathrm{mg} / \mathrm{kg}$ of Chol, respec- 
Table 2. Effect of replacing methionine with different levels of betaine and choline (mg/kg) on feed intake, weight gain, feed conversion ratio, European efficiency factor, the cost of producing $1 \mathrm{~kg}$ of live weight, and viability in broiler chicks (Trial 1)

\begin{tabular}{|c|c|c|c|c|c|c|c|c|}
\hline \multirow[b]{2}{*}{ Parameter } & \multicolumn{6}{|c|}{ Treatments } & \multirow[b]{2}{*}{ SEM } & \multirow[b]{2}{*}{ P-value } \\
\hline & Control- & Control+ & $280 \mathrm{Chol}$ & $560 \mathrm{Chol}$ & 320Bet & 640Bet & & \\
\hline \multicolumn{9}{|l|}{ ADFI, g } \\
\hline 1-21 days & 33.2 & 32.9 & 30.8 & 35.1 & 34.5 & 34.8 & 0.65 & 0.4490 \\
\hline $21-42$ days & 145.7 & 141.7 & 143.6 & 150.9 & 145.6 & 139.6 & 1.77 & 0.5759 \\
\hline $1-42$ days & 87.7 & 87.3 & 84.4 & 91.4 & 89.5 & 86.7 & 0.84 & 0.2549 \\
\hline \multicolumn{9}{|l|}{ ADWG, g } \\
\hline 1-21 days & 27.4 & 29.3 & 26.0 & 29.1 & 28.7 & 28.0 & 0.43 & 0.2201 \\
\hline 21-42 days & 71.1 & 71.0 & 75.0 & 74.7 & 71.0 & 68.4 & 1.27 & 0.6983 \\
\hline $1-42$ days & 48.5 & 50.2 & 49.3 & 51.2 & 49.6 & 48.0 & 0.61 & 0.7493 \\
\hline \multicolumn{9}{|l|}{ FCR, g/g } \\
\hline 1-21 days & 1.21 & 1.13 & 1.18 & 1.21 & 1.20 & 1.24 & 0.016 & 0.4154 \\
\hline 21-42 days & 2.06 & 2.00 & 1.92 & 2.03 & 2.06 & 2.05 & 0.020 & 0.3079 \\
\hline $1-42$ days & $1.81^{\mathrm{a}}$ & $1.72^{\mathrm{bc}}$ & $1.71^{\mathrm{c}}$ & $1.76^{\mathrm{abc}}$ & $1.79^{\mathrm{ab}}$ & $1.80^{\mathrm{a}}$ & 0.010 & 0.0314 \\
\hline \multicolumn{9}{|l|}{ EEF } \\
\hline 1-42 days & 281.0 & 300.4 & 291.5 & 285.7 & 283.1 & 280.5 & 4.56 & 0.8334 \\
\hline \multicolumn{9}{|l|}{$\mathrm{C}_{\mathrm{m}}(\$ / \mathrm{kg})$} \\
\hline 1-21 days & 19702 & 18362 & 18854 & 18740 & 19177 & 19923 & 251.1 & 0.4428 \\
\hline 22-42 days & 30661 & 30281 & 29033 & 31097 & 31200 & 31008 & 288.9 & 0.3264 \\
\hline 1-42 days & $27371^{\mathrm{a}}$ & $27147^{\mathrm{a}}$ & $26225^{\mathrm{b}}$ & $27455^{\mathrm{a}}$ & $26951^{\mathrm{ab}}$ & $27336^{\mathrm{a}}$ & 131.5 & 0.0415 \\
\hline \multicolumn{9}{|l|}{ Viability (\%) } \\
\hline $1-42$ days & 100 & 100 & 97.9 & 97.9 & 97.9 & 97.9 & 0.65 & 0.8424 \\
\hline
\end{tabular}

ADFI, average daily feed intake; ADWG, average daily weight gain; FCR, feed conversion ratio; Chol, choline; Bet, betaine; EEF, European efficiency factor; $\mathrm{Cm}$, the cost of producing $1 \mathrm{~kg}$ of meat.

${ }^{\mathrm{a}^{-c} \mathrm{c}}$ Mean values within a row with no common superscript differ significantly $(P<0.05)$.

Table 3. Effect of replacing methionine with different levels of betaine and choline (mg/kg) on feed intake, weight gain, feed conversion ratio, European efficiency factor, the cost of producing $1 \mathrm{~kg}$ of live weight, and viability in broiler chicks (Trial 2)

\begin{tabular}{|c|c|c|c|c|c|c|c|c|}
\hline \multirow[b]{2}{*}{ Parameter } & \multicolumn{6}{|c|}{ Treatments } & \multirow[b]{2}{*}{ SEM } & \multirow[b]{2}{*}{ P-value } \\
\hline & Control- & Control+ & $\begin{array}{c}140 \mathrm{Chol}^{+} \\
160 \mathrm{Bet}\end{array}$ & $\begin{array}{c}280 \mathrm{Chol}^{+} \\
160 \mathrm{Bet}\end{array}$ & $\begin{array}{c}140 \mathrm{Chol}^{+} \\
320 \mathrm{Bet}\end{array}$ & $\begin{array}{c}280 \mathrm{Chol}^{+} \\
320 \mathrm{Bet}\end{array}$ & & \\
\hline \multicolumn{9}{|l|}{ ADFI, $g$} \\
\hline 1-21 days & 32.0 & 33.1 & 30.4 & 32.1 & 35.5 & 32.6 & 0.71 & 0.5141 \\
\hline 21-42 days & 139.4 & 145.5 & 144.8 & 139.9 & 147.3 & 148.1 & 1.71 & 0.6094 \\
\hline 1-42 days & 84.5 & 88.8 & 86.4 & 85.0 & 90.3 & 88.5 & 0.90 & 0.3859 \\
\hline \multicolumn{9}{|l|}{ ADWG, $g$} \\
\hline 1-21 days & 25.3 & 29.5 & 26.3 & 25.7 & 29.0 & 27.8 & 0.57 & 0.1344 \\
\hline 21-42 days & 69.1 & 75.0 & 74.5 & 71.1 & 68.8 & 74.2 & 1.22 & 0.5319 \\
\hline 1-42 days & 46.7 & 52.0 & 49.9 & 47.9 & 48.6 & 50.2 & 0.69 & 0.3148 \\
\hline \multicolumn{9}{|l|}{ FCR, g/g } \\
\hline 1-21 days & $1.28^{\mathrm{a}}$ & $1.14^{\mathrm{c}}$ & $1.15^{\mathrm{c}}$ & $1.25^{\mathrm{ab}}$ & $1.22^{\mathrm{abc}}$ & $1.17^{\mathrm{bc}}$ & 0.016 & 0.0292 \\
\hline 21-42 days & 2.02 & 1.95 & 1.95 & 1.97 & 2.16 & 2.00 & 0.025 & 0.1071 \\
\hline 1-42 days & $1.83^{\mathrm{ab}}$ & $1.71^{\mathrm{c}}$ & $1.73^{\mathrm{bc}}$ & $1.77^{\mathrm{abc}}$ & $1.87^{\mathrm{a}}$ & $1.76^{\mathrm{bc}}$ & 0.016 & 0.0319 \\
\hline \multicolumn{9}{|l|}{$\mathrm{EEF}$} \\
\hline 1-42 days & $261.6^{\mathrm{b}}$ & $313.6^{\mathrm{a}}$ & $294.9^{\mathrm{ab}}$ & $286.5^{\mathrm{ab}}$ & $289.8^{\mathrm{ab}}$ & $297.6^{\mathrm{a}}$ & 5.13 & 0.0391 \\
\hline \multicolumn{9}{|l|}{$\mathrm{C}_{\mathrm{m}}(\$ / \mathrm{kg})$} \\
\hline 1-21 days & $20341^{\mathrm{a}}$ & $18435^{\mathrm{c}}$ & $18395^{\mathrm{c}}$ & $20039^{\mathrm{ab}}$ & $19543^{\mathrm{abc}}$ & $18736^{\mathrm{bc}}$ & 234.7 & 0.026 \\
\hline 22-42 days & 30943 & 29952 & 30093 & 30485 & 33479 & 31039 & 376.1 & 0.074 \\
\hline 1-42 days & $27915^{\mathrm{ab}}$ & $26643^{\mathrm{b}}$ & $26961^{\mathrm{b}}$ & $27632^{\mathrm{b}}$ & $29153^{\mathrm{a}}$ & $27518^{\mathrm{b}}$ & 237.1 & 0.026 \\
\hline \multicolumn{9}{|l|}{ Viability (\%) } \\
\hline $1-42$ days & 100 & 100 & 97.9 & 100 & 100 & 100 & 0.32 & 0.37 \\
\hline
\end{tabular}

ADFI, average daily feed intake; ADWG, average daily weight gain; FCR, feed conversion ratio; Chol, choline; Bet, betaine; $1 \$=35700$ Rail; EEF, European efficiency factor; $\mathrm{Cm}$, the cost of producing $1 \mathrm{~kg}$ of meat.

${ }^{\mathrm{a}-\mathrm{c}}$ Mean values within a row with different superscripts differ significantly $(P<0.05)$. 
Table 4. Effect of replacing methionine with different levels of betaine and choline ( $\mathrm{mg} / \mathrm{kg}$ ) on organ weight and total lipid content of the liver in broiler chicks (Trial 1)

\begin{tabular}{|c|c|c|c|c|c|c|c|c|}
\hline \multirow[b]{2}{*}{ Parameter } & \multicolumn{6}{|c|}{ Treatments } & \multirow[b]{2}{*}{ SEM } & \multirow[b]{2}{*}{ P-value } \\
\hline & Control & Control+ & 280Chol & $560 \mathrm{Chol}$ & 320Bet & 640Bet & & \\
\hline Feathers removed* & 92.8 & 93.9 & 93.7 & 93.2 & 93.4 & 93.4 & 0.19 & 0.6742 \\
\hline Carcass & 69.1 & 71.1 & 70.8 & 69.7 & 69.8 & 70.4 & 0.30 & 0.3687 \\
\hline Breast & 23.7 & 25.0 & 24.3 & 24.9 & 23.8 & 23.9 & 0.26 & 0.5569 \\
\hline Thigh + drumstick & $20.5^{\mathrm{a}}$ & $19.8^{\mathrm{ab}}$ & $19.2^{\mathrm{b}}$ & $19.7^{\mathrm{ab}}$ & $19.7^{\mathrm{ab}}$ & $20.6^{\mathrm{a}}$ & 0.14 & 0.0283 \\
\hline Back & 24.6 & 23.4 & 24.2 & 23.8 & 23.7 & 24.9 & 0.19 & 0.1182 \\
\hline Digestive system & 13.2 & 12.6 & 13.6 & 13.4 & 13.6 & 12.7 & 0.15 & 0.2172 \\
\hline Gizzard & 3.09 & 3.05 & 3.13 & 3.02 & 3.08 & 2.79 & 0.057 & 0.6241 \\
\hline Proventriculus & $0.46^{\mathrm{b}}$ & $0.45^{\mathrm{b}}$ & $0.52^{\mathrm{ab}}$ & $0.47^{\mathrm{b}}$ & $0.51^{\mathrm{ab}}$ & $0.55^{\mathrm{a}}$ & 0.010 & 0.0171 \\
\hline Liver & $2.57^{\mathrm{b}}$ & $2.68^{\mathrm{ab}}$ & $2.94^{\mathrm{a}}$ & $2.96^{\mathrm{a}}$ & $2.52^{\mathrm{b}}$ & $2.40^{\mathrm{b}}$ & 0.050 & 0.0023 \\
\hline Spleen & 0.14 & 0.12 & 0.11 & 0.14 & 0.11 & 0.13 & 0.005 & 0.3844 \\
\hline Heart & 0.53 & 0.48 & 0.53 & 0.50 & 0.51 & 0.55 & 0.009 & 0.2736 \\
\hline Bursa Fabricius & 0.11 & 0.09 & 0.11 & 0.11 & 0.09 & 0.11 & 0.006 & 0.5468 \\
\hline $\begin{array}{l}\text { Total lipid content } \\
\text { of liver }(\%)\end{array}$ & $26.5^{\mathrm{ab}}$ & $24.5^{\mathrm{ab}}$ & $33.1^{\mathrm{a}}$ & $25.0^{\mathrm{ab}}$ & $22.7^{\mathrm{b}}$ & $18.7^{\mathrm{b}}$ & 1.13 & 0.0176 \\
\hline
\end{tabular}

* Relative weight to live body weight for feathers removed, and carcass weight and relative weight to carcass weight for others; Chol, choline; Bet, betaine.

${ }^{\mathrm{a}-\mathrm{c}}$ Mean values within a row with different superscripts differ significantly $(P<0.05)$. Values represent 4 replicates of 2 birds per replicate for each treatment.

Table 5. Effect of replacing methionine with different levels of betaine and choline ( $\mathrm{mg} / \mathrm{kg}$ ) on organ weight and total liver lipid concentration in broiler (Trial 2)

\begin{tabular}{|c|c|c|c|c|c|c|c|c|}
\hline \multirow[b]{2}{*}{ Parameter } & \multicolumn{6}{|c|}{ Treatments } & \multirow[b]{2}{*}{ SEM } & \multirow[b]{2}{*}{ P-value } \\
\hline & Control- & Control+ & $\begin{array}{c}140 \mathrm{Chol}^{+} \\
160 \mathrm{Bet}\end{array}$ & $\begin{array}{c}280 \mathrm{Chol}+ \\
160 \mathrm{Bet}\end{array}$ & $\begin{array}{c}\text { 140Chol+ } \\
\text { 320Bet }\end{array}$ & $\begin{array}{l}280 \mathrm{Chol}^{+} \\
320 \mathrm{Bet}\end{array}$ & & \\
\hline Feathers removed* & 92.7 & 93.7 & 93.4 & 94.5 & 93.0 & 93.3 & 0.48 & 0.9397 \\
\hline Carcass & 68.7 & 67.4 & 71.6 & 71.4 & 70.2 & 69.8 & 0.75 & 0.5828 \\
\hline Breast & 23.8 & 24.6 & 26.1 & 26.0 & 25.2 & 25.1 & 0.30 & 0.2110 \\
\hline Thigh + drumstick & 20.1 & 19.8 & 19.7 & 20.0 & 20.0 & 19.8 & 0.10 & 0.8597 \\
\hline Back & 24.4 & 23.2 & 24.6 & 24.3 & 24.3 & 24.8 & 0.24 & 0.5115 \\
\hline Digestive system & 13.4 & 13.2 & 12.2 & 13.2 & 12.7 & 13.7 & 0.18 & 0.2726 \\
\hline Gizzard & $3.00^{\mathrm{bc}}$ & $3.03^{\mathrm{bc}}$ & $2.78^{\mathrm{c}}$ & $3.21^{\mathrm{ab}}$ & $3.00^{\mathrm{bc}}$ & $3.44^{\mathrm{a}}$ & 0.056 & 0.0208 \\
\hline Proventriculus & 0.46 & 0.5 & 0.48 & 0.5 & 0.48 & 0.53 & 0.013 & 0.6830 \\
\hline Liver & 2.63 & 2.65 & 2.4 & 2.38 & 2.55 & 2.69 & 0.037 & 0.0503 \\
\hline Spleen & 0.14 & 0.12 & 0.1 & 0.12 & 0.14 & 0.12 & 0.005 & 0.1749 \\
\hline Heart & 0.51 & 0.48 & 0.5 & 0.52 & 0.49 & 0.51 & 0.008 & 0.6675 \\
\hline Bursa of Fabricius & $0.08^{\mathrm{ab}}$ & $0.09^{\mathrm{ab}}$ & $0.07^{\mathrm{b}}$ & $0.06^{\mathrm{b}}$ & $0.11^{\mathrm{a}}$ & $0.11^{\mathrm{a}}$ & 0.005 & 0.0068 \\
\hline $\begin{array}{l}\text { Total lipid content } \\
\text { of liver }(\%)\end{array}$ & $24.4^{\mathrm{a}}$ & $25.9^{\mathrm{a}}$ & $22.6^{\mathrm{a}}$ & $14.8^{\mathrm{b}}$ & $21.7^{\mathrm{a}}$ & $21.0^{\mathrm{a}}$ & 0.97 & 0.0153 \\
\hline
\end{tabular}

* Relative weight to live body weight for feathers removed, and carcass weight and relative weight to carcass weight for others; Chol, choline; Bet, betaine.

${ }^{\mathrm{a}^{-} \mathrm{c}}$ Mean values within a row with different superscripts differ significantly $(P<0.05)$. Values represent 4 replicates of 2 birds per replicate for each treatment.

tively $(P<0.05$; Table 6). Habibian et al. (2014) showed that serum concentrations of total cholesterol and LDL increased in heat-stressed broilers, owing to the lipotropic effect of betaine (Cholewa et al., 2014). Betaine can stimulate lipolysis and inhibit lipogenesis via gene expression and the subsequent activity of lipolytic-/lipogenicrelated proteins (Cholewa et al., 2014).
We did not observe any significant changes in the activities of liver enzymes (ALT, AST, and ALP), or in hemoglobin and malondialdehyde (MDA) concentrations in the present study $(P>0.05$; Table 8 and Table 9$)$. Owing to a higher blood uric acid concentration, the serum total antioxidant status (Trial 1) was significantly greater in the control+ chicks than in the other chicks, with the exception of 
Table 6. Effect of replacing methionine with different levels of betaine and choline (mg/kg) on blood parameters in broilers (Trial 1)

\begin{tabular}{lcccccccc}
\hline \hline & \multicolumn{7}{c}{ Treatments } \\
\cline { 2 - 6 } \multicolumn{1}{c}{ Parameter } & Control- & Control+ & 280 Chol & 560 Chol & 320 Bet & 640 Bet & SEM & P-value \\
\hline ALB (g/dL) & 1.48 & 1.43 & 1.44 & 1.46 & 1.58 & 1.44 & 0.019 \\
TP (g/dL) & 3.46 & 3.43 & 3.65 & 3.54 & 3.58 & 3.20 & 0.045 & 0.1860 \\
GLU (mg/dL) & 191.2 & 186.9 & 198.5 & 201.7 & 198.4 & 189.0 & 2.79 & 0.0860 \\
Ca (mg/dL) & 8.90 & 8.95 & 9.11 & 9.58 & 8.49 & 9.28 & 0.261 & 0.8940 \\
P (mg/dL) & 4.77 & 4.53 & 4.90 & 4.46 & 4.09 & 4.96 & 0.108 & 0.1915 \\
TG (mg/dL) & 36.7 & 46.9 & 36.9 & 46.2 & 48.5 & 44.6 & 1.94 & 0.2965 \\
CHL (mg/dL) & 130.1 & 127.3 & 128.4 & 127.3 & 133.6 & 116.3 & 2.43 & 0.2655 \\
HDL (mg/dL) & 81.2 & 81.2 & 80.8 & 77.0 & 78.0 & 67.5 & 2.01 \\
LDL (mg/dL) & $41.5^{\text {ab }}$ & $30.9^{\mathrm{b}}$ & $40.1^{\text {ab }}$ & $33.1^{\mathrm{b}}$ & $51.3^{\mathrm{a}}$ & $40.5^{\text {ab }}$ & 1.79 & 0.1670 \\
VLDL (mg/dL) & 7.69 & 9.38 & 7.37 & 9.25 & 9.71 & 8.92 & 0.386 & 0.0091 \\
NEFA (mmol/L) & 0.38 & 0.37 & 0.35 & 0.37 & 0.43 & 0.42 & 0.015 & 0.6490 \\
\hline
\end{tabular}

ALB, albumin; TP, total protein; GLU, glucose; Ca, calcium; P, phosphorus; TG, triglyceride; CHL, total cholesterol; HDL, high-density lipoprotein; LDL, low-density lipoprotein; VLDL, very low-density lipoprotein; NEFA, non-esterified fatty acid; Chol, choline; Bet, betaine.

${ }^{\mathrm{a}^{-\mathrm{c}} \mathrm{C}}$ Mean values within a row with different superscripts differ significantly $(P<0.05)$. Values represent 4 replicates of 2 birds per replicate for each treatment.

Table 7. Effect of replacing methionine with different levels of betaine and choline (mg/kg) on blood parameters in broilers (Trial 2)

\begin{tabular}{|c|c|c|c|c|c|c|c|c|}
\hline \multirow[b]{2}{*}{ Parameter } & \multicolumn{6}{|c|}{ Treatments } & \multirow[b]{2}{*}{ SEM } & \multirow[b]{2}{*}{ P-value } \\
\hline & Control & Control+ & $\begin{array}{c}140 \text { Chol+ } \\
160 \text { Bet }\end{array}$ & $\begin{array}{c}280 \text { Chol+ } \\
160 \text { Bet }\end{array}$ & $\begin{array}{l}140 \text { Chol+ } \\
320 \text { Bet }\end{array}$ & $\begin{array}{l}280 \text { Chol+ } \\
320 \text { Bet }\end{array}$ & & \\
\hline ALB (g/dL) & 1.48 & 1.36 & 1.35 & 1.47 & 1.56 & 1.46 & 0.023 & 0.0874 \\
\hline $\mathrm{TP}(\mathrm{g} / \mathrm{dL})$ & 3.55 & 3.29 & 3.36 & 3.50 & 3.71 & 3.45 & 0.050 & 0.2038 \\
\hline GLU (mg/dL) & 196.6 & 189.5 & 191.1 & 200.5 & 198.6 & 213.2 & 3.25 & 0.2895 \\
\hline $\mathrm{P}(\mathrm{mg} / \mathrm{dL})$ & 8.80 & 4.50 & 4.65 & 5.18 & 4.74 & 4.69 & 0.117 & 0.7148 \\
\hline TG (mg/dL) & 40.9 & 47.1 & 42.5 & 43.6 & 45.9 & 39.2 & 1.66 & 0.7517 \\
\hline CHL (mg/dL) & 129.3 & 126.3 & 124.0 & 122.0 & 131.9 & 125.2 & 2.96 & 0.9595 \\
\hline HDL (mg/dL) & 76.3 & 60.5 & 69.3 & 76.1 & 84.2 & 73.9 & 2.29 & 0.5635 \\
\hline $\mathrm{LDL}(\mathrm{mg} / \mathrm{dL})$ & 44.8 & 36.4 & 46.2 & 37.3 & 38.5 & 38.4 & 2.26 & 0.7206 \\
\hline VLDL (mg/dL) & 8.18 & 9.42 & 8.50 & 8.71 & 9.17 & 7.85 & 0.332 & 0.7517 \\
\hline
\end{tabular}

ALB, albumin; TP, total protein; GLU, glucose; Ca, calcium; P, phosphorus; TG, triglyceride; CHL, total cholesterol; HDL, high-density lipoprotein; LDL, low-density lipoprotein; VLDL, very low-density lipoprotein; NEFA, non-esterified fatty acid; Chol, choline; Bet, betaine.

${ }^{a^{-c}}$ Mean values within a row with different superscripts differ significantly $(P<0.05)$. Values represent 4 replicates of 2 birds per replicate for each treatment.

the 320Bet-fed birds $(P<0.05)$. Glutathione peroxidase activity increased in the birds fed a Met-deficient diet supplemented with $320 \mathrm{mg} / \mathrm{kg}$ Bet $(P<0.05)$, but supplementation with $640 \mathrm{mg} / \mathrm{kg}$ Bet caused no further elevation in the activity of GPx (Table 8).

In Trial 2, GPx activity increased in the birds fed $140 \mathrm{Chol}$ +160Bet and 140Chol+320Bet diets (Table 9). The glutathione antioxidant enzymatic system plays an important role in cellular defense against reactive oxygen species (ROS) (Alirezaei et al., 2012). Glutathione peroxidase (GPx) and superoxide dismutase (SOD), which are responsible for the destruction of peroxides, have specific roles in protecting tissues from oxidative damage (Sun et al., 2008; Ganesan et al., 2011). A reduction in the activity of these enzymes may lead to the formation of $\mathrm{O}_{2}$ - and $\mathrm{H}_{2} \mathrm{O}_{2}$ when birds experience oxidative stress, which in turn can lead to increased hydroxyl radical formation with harmful consequences (Kalra et al., 1988). In the Met-deficient diets, there was increased excretion of nitrogen in the form of uric acid, probably due to an amino acids imbalance. Excess or imbalanced dietary amino acids split into a carbon skeleton and ammonia, which birds convert to uric acid (Namroud et al., 2008), a wellknown and powerful antioxidant agent (Glantzounis et al., 2005; Maiuolo et al., 2016). Therefore, the higher total antioxidant status observed in the birds fed a Met-sufficient diet (control+) in Trial 1 can be attributed to the increased 
Table 8. Effect of replacing methionine with different levels of betaine and choline (mg/kg) on blood liver enzymes and status of antioxidative factors in broilers (Trial 1)

\begin{tabular}{|c|c|c|c|c|c|c|c|c|}
\hline \multirow[b]{2}{*}{ Parameter } & \multicolumn{6}{|c|}{ Treatments } & \multirow[b]{2}{*}{ SEM } & \multirow[b]{2}{*}{ P-value } \\
\hline & Control- & Control + & 280 Chol & 560 Chol & 320 Bet & 640 Bet & & \\
\hline ALP (U/L) & 5373 & 4576 & 5741 & 5063 & 5365 & 4666 & 298.8 & 0.8790 \\
\hline AST (U/L) & 222.9 & 250.7 & 263.5 & 258.7 & 267.9 & 263.6 & 8.35 & 0.5961 \\
\hline ALT (U/L) & 10.5 & 8.9 & 9.1 & 11.4 & 9.6 & 11.5 & 0.83 & 0.9153 \\
\hline TAS (mmol/L) & $1.32^{\mathrm{b}}$ & $1.70^{\mathrm{a}}$ & $1.22^{\mathrm{b}}$ & $1.27^{\mathrm{b}}$ & $1.48^{\mathrm{ab}}$ & $1.30^{\mathrm{b}}$ & 0.047 & 0.0179 \\
\hline SOD (U/g Hb) & 100.1 & 97.7 & 120.5 & 102.4 & 118.2 & 94.7 & 4.19 & 0.3586 \\
\hline GPx (U/g Hb) & $42.9^{\mathrm{b}}$ & $48.7^{\mathrm{b}}$ & $49.0^{\mathrm{b}}$ & $49.5^{\mathrm{b}}$ & $70.7^{\mathrm{a}}$ & $55.2^{\mathrm{ab}}$ & 2.56 & 0.0310 \\
\hline MDA (nmol/mL) & 1.86 & 2.04 & 2.29 & 1.89 & 1.90 & 1.83 & 0.072 & 0.5020 \\
\hline Uric acid (mg/dL) & $2.28^{\mathrm{b}}$ & $3.71^{\mathrm{a}}$ & $1.91^{\mathrm{b}}$ & $2.77^{\mathrm{ab}}$ & $2.71^{\mathrm{ab}}$ & $2.41^{\mathrm{b}}$ & 0.151 & 0.0079 \\
\hline $\mathrm{Hb}(\mathrm{g} / \mathrm{dL})$ & 10.4 & 11.3 & 10.6 & 11.1 & 11.0 & 11.2 & 0.18 & 0.6186 \\
\hline SAA $(\mu \mathrm{g} / \mathrm{mL})$ & 2.63 & 2.91 & 3.03 & 3.03 & 3.08 & 2.90 & 0.083 & 0.6545 \\
\hline CEP $(\mu \mathrm{g} / \mathrm{L})$ & 1486 & 1461 & 1470 & 1510 & 1389 & 1384 & 21.8 & 0.4953 \\
\hline
\end{tabular}

ALP, alkaline phosphatase; AST, aspartate amino transferase; ALT, alanine amino transferase; TAS, total antioxidant status; SOD, superoxide dismutase; GPx, glutathione peroxidase; MDA, malondialdehyde; Hb, hemoglobin; SAA, serum amyloid A; CEP, ceruloplasmin; Chol, choline; Bet, betaine.

${ }^{\mathrm{a}^{-c} \mathrm{c}}$ Mean values within a row with different superscripts differ significantly $(P<0.05)$. Values represent 4 replicates of 2 birds per replicate for each treatment.

Table 9. Effect of replacing methionine with different levels of betaine and choline ( $\mathrm{mg} / \mathrm{kg})$ on blood liver enzymes and status of antioxidative factors in broilers (Trial 2)

\begin{tabular}{|c|c|c|c|c|c|c|c|c|}
\hline \multirow[b]{2}{*}{ Parameter } & \multicolumn{6}{|c|}{ Treatments } & \multirow[b]{2}{*}{ SEM } & \multirow[b]{2}{*}{ P-value } \\
\hline & Control- & Control+ & $\begin{array}{c}140 \mathrm{Chol}^{+} \\
160 \mathrm{Bet}\end{array}$ & $\begin{array}{c}280 \mathrm{Chol}^{+} \\
160 \mathrm{Bet}\end{array}$ & $\begin{array}{l}140 \mathrm{Chol}^{+} \\
320 \mathrm{Bet}\end{array}$ & $\begin{array}{c}280 \mathrm{Chol}^{+} \\
320 \mathrm{Bet}\end{array}$ & & \\
\hline ALP (U/L) & 5368 & 4249 & 4024 & 5737 & 5687 & 5433 & 306.0 & 0.4361 \\
\hline AST (U/L) & 219.1 & 242.7 & 218.4 & 247.0 & 234.7 & 251.1 & 8.16 & 0.7898 \\
\hline ALT (U/L) & 11.8 & 8.7 & 6.0 & 9.6 & 10.6 & 13.1 & 0.98 & 0.1970 \\
\hline TAS (mmol/L) & 1.48 & 1.51 & 1.44 & 1.71 & 1.37 & 1.48 & 0.053 & 0.6865 \\
\hline SOD (U/g Hb) & 92.2 & 89.4 & 118.4 & 93.3 & 100.7 & 79.2 & 4.58 & 0.2207 \\
\hline GPx (U/g Hb) & $41.9^{\mathrm{b}}$ & $43.0^{\mathrm{b}}$ & $65.2^{\mathrm{a}}$ & $52.5^{\mathrm{ab}}$ & $68.3^{\mathrm{a}}$ & $47.1^{\mathrm{b}}$ & 2.93 & 0.0119 \\
\hline $\mathrm{MDA}(\mathrm{nmol} / \mathrm{mL})$ & 2.13 & 2.00 & 2.26 & 1.84 & 1.91 & 2.01 & 0.085 & 0.8069 \\
\hline Uric acid $(\mathrm{mg} / \mathrm{dL})$ & 2.78 & 3.21 & 2.91 & 3.55 & 2.75 & 3.15 & 0.175 & 0.8145 \\
\hline $\mathrm{Hb}(\mathrm{g} / \mathrm{dL})$ & 9.2 & 11.3 & 13.3 & 11.0 & 13.0 & 11.3 & 0.57 & 0.3484 \\
\hline $\mathrm{SAA}(\mu \mathrm{g} / \mathrm{mL})$ & 2.08 & 2.33 & 2.14 & 2.37 & 2.25 & 2.41 & 0.082 & 0.8512 \\
\hline CEP $(\mu \mathrm{g} / \mathrm{L})$ & 1479 & 1451 & 1431 & 1413 & 1501 & 1442 & 26.6 & 0.9595 \\
\hline
\end{tabular}

ALP, alkaline phosphatase; AST, aspartate amino transferase; ALT, alanine amino transferase; TAS, total antioxidant status; SOD, superoxide dismutase; GPx, glutathione peroxidase; MDA, malondialdehyde; Hb, hemoglobin; SAA, serum amyloid A; CEP, ceruloplasmin; Chol, choline; Bet, betaine.

${ }^{a^{-c}}$ Mean values within a row with different superscripts differ significantly $(P<0.05)$. Values represent 4 replicates of 2 birds per replicate for each treatment.

levels of circulatory uric acid (Table 8). Uric acid, which is the most abundant aqueous antioxidant, accounts for up to $60 \%$ of plasma antioxidative capacity in birds. It is a free radical scavenger that stabilizes vitamin $\mathrm{C}$ in the serum, mostly owing to its iron-chelating properties, and quenches peroxynitrite, a potentially harmful oxidant, resulting in the formation of a stable nitric oxide (NO) donor in vitro (Maiuolo et al., 2016).

Our results showed that TAS is not an appropriate indication of antioxidant capacity in birds fed amino acid-deficient or imbalanced diets because of the elevated serum concentration of uric acid, which acts as an antioxidant. Therefore, under such conditions, the activities of antioxidant enzymes such as GPx and SOD should be considered antioxidative indices.

In Trials 1 and 2 (Tables 8 and 9), the serum SAA and CEP concentrations were not affected by the dietary treatments $(P>0.05)$, but were slightly higher than the normal ranges reported for chickens (Nazifi et al., 2011; O'Reilly and Eckersall, 2014). Heat stress increases the serum concentration of ceruloplasmin in broilers (Lin et al., 2006b). Serum amyloid A and CEP are acute-phase proteins, and 
their circulatory concentrations are supposed to increase in animals subjected to external or internal challenges such as infection, inflammation, surgical trauma, or stress (Eckersall, 2004).

In conclusion, the present study showed that up to $20 \%$ of the dietary Met requirements of broiler chickens exposed to heat stress can be fulfilled by Chol $(280 \mathrm{Chol}$ and $560 \mathrm{Chol})$ and Bet (320Bet and 140Chol+160Bet), without adversely affecting production performance. The cost of meat production per $\mathrm{kg}$ decreased in birds fed the Met-deficient diet supplemented with $280 \mathrm{mg} / \mathrm{kg}$ of Chol. Supplementing diets with $280 \mathrm{mg}$ Chol and $640 \mathrm{mg} / \mathrm{kg}$ of Bet reduces the serum uric acid concentration, which in turn may reduce its excretion, thereby reducing ammonia emission in poultry houses and nitrogen emission into the environment. However, the latter warrants further investigation.

\section{Acknowledgments}

This research was financially supported by Lorestan University.

\section{References}

Aksit M, Yalcin S, Özkan S, Metin K and Özdemir D. Effects of temperature during rearing and crating on stress parameters and meat quality of broilers. Poultry Science, 85: 1867-1874. 2006.

Alirezaei M, Gheisari HR, Ranjbar VR and Hajibemani A. Betaine: a promising antioxidant agent for enhancement of broiler meat quality. British Poultry Science, 53: 699-707. 2012.

Ando M, Katagiri K, Yamamoto S, Wakamatsu K, Kawahara I, Asanuma S, Usuda M and Sasaki K. Age-related effects of heat stress on protective enzymes for peroxides and microsomal monooxygenase in rat liver. Environmental Health Perspective, 105: 726-733. 1997.

Azadmanesh V, and Jahanian R. Effect of supplemental lipotropic factors on performance, immune responses, serum metabolites and liver heath in broiler chicks fed high energy diets. Animal Feed Science and Technology, 195: 92-100. 2014.

Bera AK, Bhattacharya D, Pan D, Dhara A, Kumar S and Das SK. Evaluation of Economic Losses due to Coccidiosis in Poultry Industry in India. Agricultural Economics Research Review, 23: 91-96. 2010.

Borges SA, Da Silva AVF, Majorka A, Hooge DM and Cummings KR. Physiological responses of broiler chickens to heat stress and dietary electrolyte balance (sodium plus potassium minus chloride, milliequivalents per kilogram). Poultry Science, 83: 1551-1558. 2004.

Caylaka E, Aytekinb M and Halifeoglua I. Antioxidant effects of methionine, a-lipoic acid, $\mathrm{N}$-acetylcysteine and homocysteine on lead-induced oxidative stress to erythrocytes in rats. Experimental and Toxicologic Pathology, 60: 289-294. 2008.

Charles DR. Temperature for broilers. World's Poultry Science Journal, 42: 249-258. 1986.

Cholewa JM, Guimara es-Ferreira L, Zanchi NE. Effects of betaine on performance and body composition: a review of recent findings and potential mechanisms. Amino Acids, 46: 17851793. 2014.

Cooper MA and Washburn KW. The relationships of body temperature to weight gain, feed consumption, and feed utilization in broilers under heat stress. Poultry Science, 77: 237-242.
1998.

Craig SAS. Betaine in human nutrition. American Journal of Clinical Nutrition, 80: 539-549. 2004.

Donati YRA, Slosman DO and Polla BS. Oxidative injury and the heat shock response. Biochemical Pharmacology, 40: 25712577. 1990.

Duncan DB. Multiple range and multiple F tests. Biometrics 11: 1-42. 1955.

Eckersall PD. The time is right for acute phase protein assays. Veterinary Journal, 151: 577-584. 2004.

Esteve-Garcia E and Mack S. The effect of dl-methionine and betaine on growth performance and carcass characteristics in broilers. Animal Feed Science and Technology, 87: 85-93. 2000.

Folch J, Lees M and Stanley GHS. A simple method for the isolation and purification of total lipids from animal tissues. Journal of Biological Chemistry, 226: 497-509. 1957.

Ganesan B, Buddhan S, Anandan R, Sivakumar R and Nbinezhilan AR. Antioxidant defense of betaine against isoprenaline-induced myocardial infarction in rats. Molecular Biology Report, 37: 1319-1327. 2011.

Geraert PA, Padilha JCF and Guillaumin S. Metabolic and endocrine changes induced by heat exposure in chickens. Proceeding Nutrition Society, 52: 165A. 1993.

Glantzounis GK, Tsimoyiannis EC, Kappas AM and Galaris DA. Uric acid and oxidative stress. Current Pharmaceutical Design, 11: 4145-4151. 2005.

Habibian M, Ghazi S, Moeini MM and Abdolmohammadi A. Effects of dietary selenium and vitamin $\mathrm{E}$ on immune response and biological blood parameters of broilers reared under thermoneutral or heat stress conditions. International Journal of Biometeorology, 58: 741-752. 2014.

Hetland H, Svihus B and Krogdah A. Effects of oat hulls and wood shavings on digestion in broilers and layers fed diets based on whole or ground wheat. British Poultry Science, 44: 275-82. 2003.

Kalra J, Lautner D, Massey KL and Prasad K. Oxygen free radicals induced release of lysosomal enzymes in vitro. Molecular and Cellular Biochemistry, 84: 233-238. 1988.

Keshavarz K and Austic RE. An investigation concerning the possibility of replacing supplemental methionine with choline in practical laying rations. Poultry Science, 64: 114-118. 1985.

Lara LJ and Rostagno MH. Impact of heat stress on poultry production. Animals, 3: 356-369. 2013.

Lin H, Jiao HC, Buyse J and Decuypere E. Strategies for preventing heat stress in poultry. World's Poultry Science Journal, 62: 71-86. 2006a.

Lin H, Decuypere E and Buyse J. Acute heat stress induces oxidative stress in broiler chickens. Comparative Biochemistry and Physiology, Part A, 144: 11-17. 2006 b.

Lup F, Drinceanu D and Mierlisă D. Economic efficiency and european efficinecy factor in modifing of some raw materials proportion in chicken broilers feeding. Analele UniversităNiii din Oradea Fascicula: Ecotoxicologie, Zootehnie si Tehnologii de Industrie Alimentară. 2010.

Mahmoud K and Yaseen A. Effect of feed withdrawal and heat acclimatization on stress responses of male broiler and layertype chickens (Gallus domesticus). Asian-Australian Journal of Animal Science, 18: 1445. 2005.

Maiuolo J, Oppedisano F, Gratteri S, Muscoli C and Mollace V. Regulation of uric acid metabolism and excretion. International 
Journal of Cardiology, 213: 8-14. 2016.

Mitchell $\mathrm{M}$ and Carlisle A. The effects of chronic exposure to elevated environmental temperature on intestinal morphology and nutrient absorption in the domestic fowl (Gallus domesticus). Comparative Biochemistry and Physiology, Part A, Physiology, 101: 137-142. 1992.

Mujahid A, Yoshiki Y, Akiba Y and Toyomizu M. Superoxide radical production in chicken skeletal muscle induced by acute heat stress. Poultry Science, 84: 307-314. Nakanishi T and Burg MB. 1989. Osmoregulation of Glycerophosphorylcholine Content of Mammalian Renal Cells. American Journal of Physiology, 257: C795-801. 2005.

Namroud NF, Shivazad M and Zaghari M. Effects of fortifying low crude protein diet with crystalline amino acids on performance, blood ammonia level, and excreta characteristics of broiler chicks. Poultry Science, 87: 2250-2258. 2008.

Nazifi S, Tabande MR, Hosseinian SA, Ansar-Lari M and Safari H. Evaluation of sialic acid and acute-phase proteins (haptoglobin and serum amyloids A) in healthy and avian infection bronchitis virus-infected chicks. Comparative Clinical Pathology, 20: 69-73. 2011.

Neto MG, Pesti GM and Bakalli RI. Influence of dietary protein level on the broiler chicken's response to methionine and betaine supplements. Poultry Science, 79: 1478-1484. 2000.

Nir I, Twina Y, Grossman E and Nitsan Z. Quantitative effects of pelleting on performance, gastrointestinal tract and behaviour of meat-type chickens. British Poultry Science, 35: 589-602. 1994.

National Research Council. The Nutrient Requirements of Poultry. 9th rev ed. National Academy Press. Washington, DC, USA. 1994.

O'Reilley EL and Eckersall PD. Acute phase proteins: a review of their function, behavior and measurement in chickens. World Poultry Science Journal, 70: 27-44. 2014.

Patil SV, Ranade AS, Patil MB, Desai DN, Avari PE and Kawitkar SB. Use of betaine in broiler ration. Journal of Bombay Veterinary College, 15: 39-41. 2007.

Rao SV, Sunder GS, Reddy MR, Praharaj NK, Raju MV and Panda AK. Effect of supplementary choline on the performance of broiler breeders fed on different energy sources. British Poultry Science, 42: 362-367. 2001

Rao SV, Raju MVLN, Panda AK, Ria PS and Sunder GS. Effect of supplementing betaine on performance, carcass traits and immune responses in broiler chicken fed diets containing different concentrations of methionine. Asian-Australian Journal of Animal Science, 24: 662-669. 2011.
Sandercock DA, Hunter RR, Mitchell MA and Hocking PM. Thermoregulatory capacity and muscle membrane integrity are compromised in broilers compared with layers at the same age or body weight. British Poultry Science, 47: 322-329. 2006.

SAS Institute. SAS User's Guide: Statistics. Version 9.1 edn. Cary, NC, SAS Institute Inc. 2003.

Schafer C, Hoffmann L, Heldt K, Lornajad-Schafer MR, Brauers G, Gehrmann T, Garrow TA, Haussinger D, Mayatepek E, Schwahn BC and Schliess F. Osmotic regulation of betaine homocysteine-S-methyltransferase expression in H4IIE rat hepatoma cells. American Journal of Physiology, Gastrointestinal and Liver Physiology. 292: G1089-98. 2007.

Sun H, Yang WR, Yang ZB, Wang Y, Jiang SZ and Zhang GG. Effects of betaine supplementation to methionine deficient diet on growth performance and carcass characteristics of broilers. American Journal of Animal Veterinary Science, 3: 78-84. 2008.

Sunderman FW Jr and Nomoto S. Measurement of human serum ceruloplasmin by its p-phenylenediamine oxidase activity. Clinical Chemistry, 16: 903-910. 1970.

Swain BK and Johri TS. Effect of supplemental methionine, choline and their combinations on the performance and immune response of broilers. British Poultry Science, 41: 83-88. 2000.

Teeter RG, Smith MO, Owens FN, Arp SC, Sangiah S and Breazile JE. Chronic heat stress and respiratory alkalosis: Occurrence and treatment in broiler chicks. Poultry Science, 64: 10601064. 1985.

Toyomizu M, Tokuda M, Mujahid A and Akiba Y. Progressive alteration to core temperature, respiration and blood acid-base balance in broiler chickens exposed to acute heat stress. Poultry Science, 42: 110-118. 2005.

Waldroup PW and Fritts CA. Evaluation of separate and combined effects of choline and betaine in diets for male broilers. International Journal of Poultry Science, 4: 442-448. 2005.

Waldroup PW, Motl MA, Yan F and Fritts CA. Effects of betaine and choline on response to methionine supplementation to broiler diets formulated to industry standards. Journal of Applied Poultry Research, 15: 58-71. 2006.

Yancey PH, Clark ME, Hand SC, Bowlus RD and Somero GN. Living with water stress: Evolution of osmolyte systems. Science, 217: 1214-1222. 1982.

Zhang CX, Pan MX, Li B, Wang L, Mo XF, Chen YM, Lin FY and Ho SC. Choline and betaine intake is inversely associated with breast cancer risk: A two stage case control study in china. Cancer Science, 104: 250-258. 2013. 